\title{
Research on General Backgroud Investment Strategy
}

\author{
Chen Huimin ${ }^{1}$ china
}

Guoermi@126.com

Keywords: Twelfth Five-Year Plan; Reform of Financial System; Financial Regulation; Generalized Capitalist Market; Investment Strategy.

\begin{abstract}
Under the general background of Twelfth Five-Year Plan, it is a main subject for the public investors to maximize their profits through applying grasped financial knowledge during the period of reform of national financial system. Investors should understand investment conditions and comply with them so as to avoid risks as much as possible because risks are inevitable and you would never be prudent enough to enter into capitalist market.

It is well known that China is a socialist country. Since implementing reform and opening-up policy, our country has gradually established a socialist market economy with Chinese characteristics. When it comes to the discussion of Chinese economy, features of Chinese system should never be neglected. Central Committee of the Communist Party of China will make detailed plans for the development of Chinese economy. Exampled by the Twelfth Five-Year Plan for national economy and social development, Central Committee of the Communist Party of China puts forward the following twelve suggestions:

1.Accelerate to change economic development mode, create a new situation of scientific development

2.Adhere to the strategy of expanding domestic demand, maintain a stable and relatively fast economic development
\end{abstract}

3.Boostagricultural modernization, accelerate to construct new socialist countryside.

4.Develop modern industrial system, increase core industrial competitiveness.

5.Promote coordinated development of regions, actively and stably carry out urbanization.

6.Accelerate to construct resource-saving and environment-friendly society, improve the level of ecological civilization.

7.Deepen the enforcement of the strategy of rejuvenating China through science and education, the strategy of reinvigorating China through human resource, accelerate to construct an innovation-originated nation.

8. Strengthen social construction, establishing a perfect basic public service system.

9. Promote the development of culture, improve cultural soft strength.

10. Accelerate the speed of reform, perfect socialist market economy system.

11. Implement open strategies with mutual benefit and win-win result, further increase the level of opening up

12. People of all nationalities throughout the country should be united to fight for the realization of Twelfth Five-Year Plan

Viewing from these short twelve suggestions, we can see that economic construction is the core task of our country. Through consulting the outline of Twelfth Five-Year Plan for the national economy and social development of People's Republic of China, it can be found out that the headline 
of Chapter 48 is Deepening Reform of Financial System. The concrete content: Comprehensively promote financial reform, opening up and development. Construct a financial system with multiple organizations, efficient service, prudent supervision and controllable risks. Function of financial market will be strengthened constantly so as to provide a better service for accelerating the change of economic development mode. As the core of national economy, financial market provides basic conditions for economic development that capital accumulation can be promoted and then converted to investment. Financial activities can save the cost of social exchange which is beneficial to the development of social exchange. It is because finance has such a powerful ability that our country needs to strengthen the reform of financial system.

\section{Step 1 Deepen the reform of financial institution}

Continuously deepen the large-scale reform of financial institution owned by this state, perfect modern financial enterprise system, intensify internal governance and risk management, enhance innovation and development ability and international competitiveness.

\section{Step 2 Accelerate the construction of multi-layer financial market system}

Financial market should be developed in a great scale and financial innovation should be continuously encouraged. Direct financing ratio should be increased obviously. Though indirect financing occupies a leading position no matter in developing countries or developed countries by virtue of its unique advantages, direct financing can energize security market and create a new road for financial innovation. Monetary market should be expanded and function of liquiditymanagement should be strengthened. Monetary market has seven affiliated markets including interbank market, bank acceptance bill market, negotiable certificates of deposit market, repurchase market, short-term government bond market and money market mutual fundmarket. Expansion of each affiliated market is beneficial to maintain the liquidity of capitals.

\section{Step 3 Perfect financial regulatory mechanism}

Optimize target system of monetary policy, perfect decision-making mechanism of monetary policy, improve transmission mechanism and environment of monetary policy. Construct a counter-cyclical macroeconomic prudent management system framework, construct and perfect risk prevention system of financial risks, evaluate system and disposition mechanism.

\section{Step 4 Strengthen financial regulation}

Perfect financial regulation system, strengthen a concertedfinancial regulation system, perfect coordination mechanism among financial regulators and macroeconomic regulation and control department. Perfect local financial management system and intensify risk disposition responsibility of small and medium-sized financial institutions by local government.

Recently, one forum of Tsinghua PBCSF Global Finance Forum has attracted my attention that is the Construction and Development of Multi-Layer Capital Markets and Protection of Investors. Since I have learnt the course of financial management combined my understanding towards Twelfth Five-Year Plan, I believe that we can use what we learnt to service ourselves. A generalized capital market includes stock market, bond market, fund market, medium and long-term credit market. A 
narrow capital market includes main board market, market of middle and small-sized enterprises, growth enterprise market, outside electronic trading system and equity transaction market. Financial system includes monetary market, capital market, foreign exchange market, gold market and insurance market. As participants, we should also make some profits from this large policy environment while making fully use of our knowledge since such a policy environment is beneficial to the development of capital market.

It is presumed that we are investors and take a generalized capital market as an example. When participating in stock market, we should take some factors which may affect stock situation into consideration such as political factors, economic factors, mental factors and technical factors. Meanwhile, political factors should be neglected because stock market is under the support of this state. As to economic factors, we should mainly pay attention to fiscal policy and monetary policy. Mental factors mainly refer to our aversion of risk and expectation of desired return. Technical factors can also be ignored. Before we choose to purchase stock of a large company, we should calculate its intrinsic value. We should estimate if this stock is underestimated or overestimated through applying calculation methods of value of common stocks such as zero growth, steady growth and non-steady growth. If this stock is underestimated, we should buy it and capital asset pricing model can be used to determine its discount rate. Relative value of assessment can be found on the internet. When it comes to avoiding risks, financial derivative tool such as futures can be adopted. As to bond market, investors who disgust risks will choose state treasury bond because it is almost risk-free. However, as to investors who are in favor of risks may choose other bonds with more earnings. Factors that can affect bond include external factors and internal factors. Market interest rate is the main external factor. Internal factors include effective term, nominal interest rate, redeemable terms, tax treatment, liquidity, default risk, convertibility and deferrable possibility. As to stocks, we should also calculate the value of bond. It should be noted that bond has two indexes: duration and curve bending degree of bond.

Capital Asset Pricing Model:

$$
E(R)=R f+[E(R m)-R f] \times \beta
$$

Zero- Growth Model: $\quad$ V=Do/y

$$
\text { Constant }- \text { Growth Model : } \quad \text { V=D1/y-g }
$$

Liquidity can be increased through reducing duration. During the period of strengthening the collection of capital by Central Bank, reducing duration may be a good method to avoid the situation of insufficient fund happening in bond market. Bond, which has a big curve bending degree, may have a small range of falling price when interest rate increases. On the contrary, it may have a large range of falling price when interest rate decreases. On even ground, bonds with bigger curve bending degree can bring more profits to us. In order to avoid risks, financial derivative tool such as futures will be adopted. There are four kinds of fund available including open-end fund, closed-end fund, index fund and hedge fund. I prefer open-end fund and index fund. As to open-end fund, whose scale is changeable, has a higher liquidity, low risk while has no deadline. I pay a special preference for index fund because it dares to challenge the tradition. Following up standard \&Poor's Index 500 as well as declaring war on traditional investment theory is a typical example. The facts also prove that average return on investment of index fund is higher than active fund. In modern society, we need to 
innovate and dare to challenge the tradition which is more important to financial market. However, there are also some investors who prefer hedge fund. Operations of hedge fundsuch as purchasing stocks and putting optionare made globally. There are also many markets available for us, but the premise is that we need to master necessary financial knowledge. In this way, we can gain profits from capital market.

However, improper financial regulation gives rise to the loss of investors. Especially, financial innovation brings challenges to traditional methods of financial regulation which will make investors more easily to be exposed to risks. In order to solve this issue, on one hand, we should make multiple investments so as to reduce unsystematic risk and guarantee profits. On the other hand, we should guarantee our profits based on national laws and regulations. Tsinghua PBCSF Global Finance Forum also discusses this issue which implies that people have paid their attention to public investors. It is a meaningful phenomenon for public investors. What should be stressed is that whenever investors enter into capital market, they should always be prudent because risks are inevitable.

\section{References}

[1]The Twelfth Five-Year Plan (2011-2015)

[2] 《Macro-economics》 Gao Hong Ye

[3] 《Money and banking》 Yi Gang

[4] Tsinghua PBCSF Global Finance Forum (2014)

[5] GuanBin. Financial consumer protection scattered theory [J]. Journal of huazhong university of science and technology (social science edition), 2010. (01): 58.

[6]Liao Ailing. Shareholder base civilian trade of the investment not protected by the law of rights to the xiao fee [EB/OL]. http://funds.hexun.com/2008-03-24/104723900.html, 2010.

[7] 《The financial markets》 ZhangYiChun

[8]Chang-jian li and Zhang Gongzhan ;Based on the regulation of innovation and the legal protection of financial consumer rights and interests of developing research [journal] - hainan finance 2013 (5)

[9]Antony chan Financial consumer rights and interests protection system: comparison and reference to build a prospectie [journal] with China - ningxia social sciences, 2012 (6)

[10]《Micro-economics》 Gao Hong Ye 